\title{
THE EFFECT OF CALCIUM NITRATE ON THE PROPERTIES OF PORTLAND CEMENT PASTES AND CONCRETE HARDENING AT LOW TEMPERATURES
}

\author{
\#ASTA KIČAITË*, GINTAUTAS SKRIPKIŪNAS**, INA PUNDIENE*** \\ *Department of Building Materials and Fire Safety, Vilnius Gediminas Technical University, \\ Sauletekio av. 11, Vilnius, LT-10223, Lithuania \\ **Institute of Building Materials, Vilnius Gediminas Technical University, \\ Sauletekio av. 11, Vilnius, LT-10223, Lithuania \\ "E-mail: asta.kicaite@vgtu.lt
}

Submitted November 18, 2019; accepted January 20, 2020

\begin{abstract}
Keywords: Calcium nitrate, Portland cement, Hydration, Exothermic reaction, Acceleration, Setting time, Compressive strength, Temperature

The investigations of the effect of the $\mathrm{Ca}\left(\mathrm{NO}_{3}\right)_{2}$ dosage at different initial curing temperatures on the Portland cement hydration process and the physical and mechanical properties of Portland cement are presented in the paper. The results show that the $\mathrm{Ca}\left(\mathrm{NO}_{3}\right)_{2}$ admixture shortens the induction period of the hydration of the cement paste and reduces the maximal hydration temperature of the cement paste. The setting time of the cement paste with $\mathrm{Ca}\left(\mathrm{NO}_{3}\right)_{2}$ is about 1 hour shorter for $1 \%$ of $\mathrm{Ca}\left(\mathrm{NO}_{3}\right)_{2}$ in the cement paste. At $0^{\circ} \mathrm{C}$ and $5{ }^{\circ} \mathrm{C}$, the accelerating effect of the $\mathrm{Ca}\left(\mathrm{NO}_{3}\right)_{2}$ admixture is the most pronounced. At lower temperatures $\left(-5{ }^{\circ} \mathrm{C},-10{ }^{\circ} \mathrm{C}\right)$, only $3 \%$ of the $\mathrm{Ca}\left(\mathrm{NO}_{3}\right)_{2}$ admixture can shorten the initial setting time by about $40 \%$. The most effective application of $\mathrm{Ca}\left(\mathrm{NO}_{3}\right)_{2}$ is achieved at $-5{ }^{\circ} \mathrm{C}$. For the 2 day-specimens cured at the lower initial temperatures $\left(-5{ }^{\circ} \mathrm{C},-10^{\circ} \mathrm{C}\right)$, the higher $\mathrm{Ca}\left(\mathrm{NO}_{3}\right)_{2}$ dosages $(2-3 \%)$ significantly improve the standard strength values of the concrete.
\end{abstract}

\section{INTRODUCTION}

The construction of extensions is constantly increasing in the world. Concrete is the basis of modern structures. Construction work usually does not continue during the cold season. Negative temperatures make an impact on the use of concrete in winter conditions, in that it has an influence on the hydration processes in Portland cement. Cold weather is defined as the average daily temperature below $4{ }^{\circ} \mathrm{C}$ for more than three days. If the average daily air temperature is below $4{ }^{\circ} \mathrm{C}$, a special initial curing process must be taken into consideration in order to prevent the concrete from freezing in the beginning of the cement hydration process. In this case, it is necessary to protect the construction against any environmental impacts and the facing of the building's structure. If plastic concrete freezes, the strength of the concrete reduces by $50 \%$ [1]. The greatest negative effect of frost is observed on concrete with a high $\mathrm{W} / \mathrm{C}(0.6-0.75)$. Concrete is subjected to freeze-thaw cycles, when water freezes and later thaws and melts into water [2]. To apply concrete at low temperatures in winters, several methods are used. There are two basic methods of concrete laying: with and without heating. The concrete must be protected against freezing until the concrete's strength reaches a minimum $3.5 \mathrm{MPa}$ (ACI 306R-10) [3]. One method is the use of chemical admixtures to extend the temperature range in which the concrete can be used in the construction. Anti-freeze admixtures are chemicals that are added to the concrete mixture to lower the freezing point. They can be used at relatively low temperatures even at $-30^{\circ} \mathrm{C}$. Admixtures such as calcium chloride or calcium nitrate contain the same calcium cations as $\mathrm{C}_{3} \mathrm{~S}$ and $\mathrm{C}_{2} \mathrm{~S}$, thus, the hydration processes intensify $[1,4]$. In industry, while producing a liquid cement admixture, calcium nitrate is often used because of its cost-effectiveness and high solubility [5].

Anti-freeze admixtures work in such a way that they lower the freezing point of water and allow the cement to hydrate at low temperatures. The effectiveness of the anti-freeze admixtures is reducing the freezing point of water and is related to the eutectic point [6-8]. Nowadays, admixtures are mostly used in mixture with concrete for anti-freezing protection to achieve the required strength and binding at temperatures below freezing. These admixtures allow concrete to gain strength and allow them to set when the air temperature is below freezing [9, 10]. They protect concrete by accelerating the cement hydration. $\mathrm{NaNO}_{3}$ and $\mathrm{Ca}\left(\mathrm{NO}_{3}\right)_{2}$, like other admixtures, have been used to study the hydration processes of cement $[11,12]$. The thermal analysis usually aims to investigate the formation of calcium hydroxide as a measure of the cement hydration rate $[13,14]$. The mechanism of action of $\mathrm{Ca}\left(\mathrm{NO}_{3}\right)_{2}$ is such that increasing the 
concentration of the $\mathrm{Ca}$ ions promotes the saturation of the solution and the faster formation of $\mathrm{Ca}(\mathrm{OH})_{2}$. Over the past two decades, significant advances have been made in modelling cement hydration processes. $\mathrm{CaCl}_{2}$ accelerates the end of the induction period and significantly increases the rate of hydration. In contrast, $\mathrm{Ca}\left(\mathrm{NO}_{3}\right)_{2}$ shortens the induction period by about the same amount, but the hydration speed was then significantly lower than with $\mathrm{CaCl}_{2}$ [15].

According to Justnes, $\mathrm{Ca}\left(\mathrm{NO}_{3}\right)_{2}$ is more effective than $\mathrm{CaCl}_{2}$ as an accelerator for the hydration of belite $\left(\beta-\mathrm{C}_{2} \mathrm{~S}\right)$. However, the presence of chloride causes serious problems regarding the corrosion of the reinforcing bars embedded in the concrete members [16]. The admixtures can be divided into two groups according to the character of the effect: admixtures that lower the freezing point of the concrete (e.g., $\mathrm{NaNO}_{3}, \mathrm{NaCl}$ and others) and admixtures that speed up the binding time (potash, $\left.\mathrm{Ca}\left(\mathrm{NO}_{2}\right)_{2}+\mathrm{Ca}\left(\mathrm{NO}_{3}\right)_{2}\right)$.

Many scientists have undertaken research with nonchloride accelerating admixtures [17, 18]. Utilisation of antifreeze admixtures such as calcium nitrate $\left(\mathrm{Ca}\left(\mathrm{NO}_{3}\right)_{2}\right)$ and urea $\left(\mathrm{CO}\left(\mathrm{NH}_{2}\right)_{2}\right)$ illustrate the reduction of the water absorption for all the freeze-thaw cycles [19]. Low doses of $\mathrm{Ca}\left(\mathrm{NO}_{3}\right)_{2}$ can be used as an accelerating admixture [20-23]. Generally speaking, $\mathrm{Ca}\left(\mathrm{NO}_{3}\right)_{2}$ is a multifunctional admixture for concrete $[23,24]$ and its addition increases the long-term strength of the concrete based on CEM I [25].

In 1992, some countries used technical $\mathrm{Ca}\left(\mathrm{NO}_{3}\right)_{2}$, a complex nitrate salt of calcium and ammonium salt, with crystalline water as a concrete admixture [22, 23].

Today, most concrete admixtures suppliers offer $\mathrm{Ca}\left(\mathrm{NO}_{3}\right)_{2}$ as an accelerating admixture $[23,24] . \mathrm{Ca}\left(\mathrm{NO}_{3}\right)_{2}$ at relatively high dosages has proven to be an effective inhibitor against chloride induced corrosion of steel reinforcement in concrete [23].

A setting accelerator must give an initial setting time of at least $30 \mathrm{~min}$ at $20^{\circ} \mathrm{C}$, and a maximum $60 \%$ of the initial setting time of the reference at $5{ }^{\circ} \mathrm{C}$ measured on the mortar with an equal flow. To harden the concrete by using accelerating admixtures, $120 \%$ of the compressive strength after 1 day at $20{ }^{\circ} \mathrm{C}$ and a minimum of $130 \%$ of the compressive strength after 2 days at $5{ }^{\circ} \mathrm{C}$ shall be reached (EN 934-2:2009) [26].

The efficiency of the admixtures depends on such factors as the cement and water content, filler shape, proportions, mixing time, slump and concrete temperature.

A cement that contains tricalcium aluminate $\mathrm{C}_{3} \mathrm{~A}$ is significantly affected by $\mathrm{Ca}\left(\mathrm{NO}_{3}\right)_{2}$ and its compressive strength of the early ages is increased by almost $50 \%$ after 1 or 3 days compared to the control mixtures [27].

Some parts of the cement were replaced to $10 \%$ volcanic ash and the influence of $\mathrm{Ca}\left(\mathrm{NO}_{3}\right)_{2}$ to the properties of the concrete was also investigated. It was evident that the strength of the concrete improved by changing from 2 to $10 \%$. The setting times decreased both at the initial setting time and at the final setting time [28].

However, the effect of $\mathrm{Ca}\left(\mathrm{NO}_{3}\right)_{2}$ during the different cooling periods is not fully explained. In the present investigation, the researchers tried to estimate those factors. The paper deals with the effect of $\mathrm{Ca}\left(\mathrm{NO}_{3}\right)_{2}$ on the properties of the specimens with Portland cement CEM I R which had been cured for two days at different temperatures (from plus to minus) and further on they were also cured in water.

\section{EXPERIMENTAL}

The preparation of the cement pastes with the same water content and different $\mathrm{Ca}\left(\mathrm{NO}_{3}\right)_{2}$ admixture contents was carried out by the standard methodology for cement. The dosage of $\mathrm{Ca}\left(\mathrm{NO}_{3}\right)_{2}$ was from 0.5 to $3 \%$ of Portland cement by weight. Vicat equipment was used to determine the setting times of the Portland cement paste by the EN 196 standard. The tests were performed with a needle being penetrated every 10 minutes. The tests were carried out at various cement paste curing temperatures at $-10,-5,0,+5$ and $+20^{\circ} \mathrm{C}$

For the concrete mixture's preparation: the coarse aggregate - crushed gravel fraction $4 / 16$ and the fine aggregate sand fraction $0 / 4$ was used corresponding to the EN 12620 standard. A polycarboxylate ether type superplasticizer was used for the concrete mixture's preparation. For $1 \mathrm{~m}^{3}$ of concrete, the quantities of the materials used were: $310 \mathrm{~kg}$ of Portland cement, $925 \mathrm{~kg}$ of sand and $1005 \mathrm{~kg}$ of crushed gravel. $0.5 \%$ of the superplasticizer from the cement content was used for all the concrete mixtures. The water/cement ratio for all the mixtures was the same -0.55 .

The concrete mixture with and without the calcium nitrate admixtures was mixed in a pan type laboratory mixer. The mixing time lasted for 3 minutes.

Table 2. The mineral composition of the Portland cement CEM I 42.5 R.

\begin{tabular}{lcccc}
\hline Cement type & $\begin{array}{c}\mathrm{C}_{3} \mathrm{~S} \\
\text { (alite) }\end{array}$ & $\begin{array}{c}\mathrm{C}_{2} \mathrm{~S} \\
\text { (belite) }\end{array}$ & $\begin{array}{c}\mathrm{C}_{3} \mathrm{~A} \\
\text { (aluminate) }\end{array}$ & $\begin{array}{c}\mathrm{C}_{4} \mathrm{AF} \\
\text { (ferrite) }\end{array}$ \\
\hline CEM I 42.5 R & $64.6 \%$ & $7.8 \%$ & $6.4 \%$ & $12.8 \%$ \\
\hline
\end{tabular}

Table 1. The properties of the Portland cement CEM I 42.5 R.

\begin{tabular}{|c|c|c|c|c|c|}
\hline \multirow{2}{*}{ Cement type } & \multicolumn{2}{|c|}{ Compressive strength, (MPa) } & \multirow{2}{*}{$\begin{array}{c}\text { Water } \\
\text { content }(\%)\end{array}$} & \multicolumn{2}{|l|}{ Fineness } \\
\hline & 7 days & 28 days & & Blaine, $\left(\mathrm{cm}^{2} \cdot \mathrm{g}^{-1}\right)$ & $>90 \mu \mathrm{m}(\%)$ \\
\hline CEM I $42.5 \mathrm{R}$ & 28.9 & 54.6 & 25.4 & 3560 & 1.1 \\
\hline
\end{tabular}


The cement paste hardening kinetics was followed by the exothermic (EXO) profile, according to the Alcoa methodology [29]. The water/cement ratio for all the pastes was -0.3 . The fresh cement paste heat development, resulting from the exothermic reaction of the cement hydration, was determined at $22{ }^{\circ} \mathrm{C} \pm 3{ }^{\circ} \mathrm{C}$ with the fresh $1.5 \mathrm{~kg}$ cement paste samples, placed in an insulated $10 \times 10 \times 10 \mathrm{~cm}$ textolite chamber. A thermocouple (type T) was embedded in the sample, and it was linked to a data capture system and the temperature was recorded as a function of time. The temperature was measured for $48 \mathrm{~h}$.

The slump of the concrete mixture was determined by EN 12350-2 and the density of the concrete mixture was determined according to EN 12350- 6. The $100 \times$ $\times 100 \times 100 \mathrm{~mm}$ specimens were formed in steel moulds using vibration and stored for 2 days initial curing at the different temperatures in the freezing chamber -10 , $-5,0,+5$ and $+20{ }^{\circ} \mathrm{C}$, and later they were cured for 26 days at $20^{\circ} \mathrm{C}$ in water according per the EN 12390-2 requirements. The compressive strength of the concrete was tested according to EN 12390-3.

\section{RESULTS AND DISCUSSION}

\section{Temperature and rate of the cement hydration}

The exothermic temperature curves help to monitor the hydration process of the cement paste. Usually, the hydration process is presented in 3 steps: firstly, when the temperature does not change or it minimally changes (the beginning of the hydrate formation occurs (induction period, normally (3 - 4) h)), secondly, the temperature sharply increases (massive precipitation of hydrates with a progressive transition from amorphous to crystallised forms, the mixture stiffens (a quick structure compaction period, until $24 \mathrm{~h}$ )), and thirdly, the temperature decreases and becomes stable (then OPC skeletons approach its

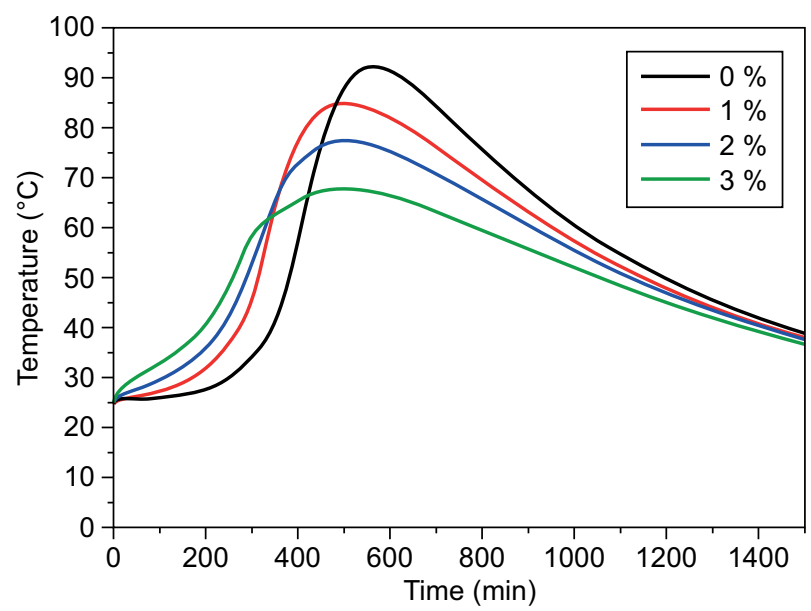

Figure 1. The exothermic temperature curves for the Portland cement CEM I $42.5 \mathrm{R}$ pastes with the different $\mathrm{Ca}\left(\mathrm{NO}_{3}\right)_{2}$ dosages. final stiffness (a slow structure compaction period, follows up for $24 \mathrm{~h}$ )). The results (Figure 1) show that in the reference with the cement paste without $\mathrm{Ca}\left(\mathrm{NO}_{3}\right)_{2}$, the induction period is the longest - about $3 \mathrm{~h} ; 1 \%$ $\mathrm{Ca}\left(\mathrm{NO}_{3}\right)_{2}$ shortens the induction period which is about 2 hours, $2 \% \mathrm{Ca}\left(\mathrm{NO}_{3}\right)_{2}$ - about 1 hour, and in the cement paste with $3 \% \mathrm{Ca}\left(\mathrm{NO}_{3}\right)_{2}$, induction period is practically absent - the temperature suddenly starts to increase immediately after the beginning of measurement (about 10 minutes after the start of the mixing). It should be noted that the higher the dose of $\mathrm{Ca}\left(\mathrm{NO}_{3}\right)_{2}$, the lower the paste temperature is during hydration. This indicates that the hydration reaction begins immediately at a higher $\mathrm{Ca}\left(\mathrm{NO}_{3}\right)_{2}$ dose. It should be noted that at $3 \% \mathrm{Ca}\left(\mathrm{NO}_{3}\right)_{2}$, the hydration temperature of the sample rose by $7{ }^{\circ} \mathrm{C}$ during the first hour. It was observed that at the end of the induction period, there was a sharp increase in the paste temperature; the higher the $\mathrm{Ca}\left(\mathrm{NO}_{3}\right)_{2}$ dose is, the shorter the time to reach the maximum temperature is. The higher the $\mathrm{Ca}\left(\mathrm{NO}_{3}\right)_{2}$ dose, the shorter the time to reach the temperature maximum. It was reached at the $3 \% \mathrm{Ca}\left(\mathrm{NO}_{3}\right)_{2}$ dose, where the maximum hydration temperature was reached in $7 \mathrm{~h}, 2 \%$ in $7.5 \mathrm{~h}, 1 \%$ in $8.5 \mathrm{~h}$, and the control in 10 hours. However, the higher the $\mathrm{Ca}\left(\mathrm{NO}_{3}\right)_{2}$ dose in the composition is, the lower the maximum temperature is. The temperature maximum reaches $91.87{ }^{\circ} \mathrm{C}$ in the control sample. With $1 \%$ $\mathrm{Ca}\left(\mathrm{NO}_{3}\right)_{2}$, the hydration temperature drops to $84.8{ }^{\circ} \mathrm{C}$, with $2 \%$ - to $77{ }^{\circ} \mathrm{C}$ and with $3 \%$ - to $67.91{ }^{\circ} \mathrm{C}$. The $\mathrm{Ca}\left(\mathrm{NO}_{3}\right)_{2}$ admixture shortens the induction period, it also raises the initial paste temperature and accelerates the maximum temperature time, but significantly reduces the maximum hydration temperature.

\section{Setting time of the Portland cement at the different temperatures}

The setting times (initial and final) of the normal consistency paste were tested at different temperatures: $+20{ }^{\circ} \mathrm{C},+5{ }^{\circ} \mathrm{C}, 0{ }^{\circ} \mathrm{C}$ (Figures 2 and 3). All the investigations were performed at the provided temperatures. Different $\mathrm{Ca}\left(\mathrm{NO}_{3}\right)_{2}$ doses were used: $0 \%, 1 \%, 2 \%$ and $3 \%$.

At $+20^{\circ} \mathrm{C}$ (Figure 2), the setting time of the normal consistency cement paste without the $\mathrm{Ca}\left(\mathrm{NO}_{3}\right)_{2}$ admixture begins after 149 minutes, at $5{ }^{\circ} \mathrm{C}$, the initial setting time is nearly two times longer and reaches 285 minutes and at $0{ }^{\circ} \mathrm{C}$, the initial setting time is the highest and starts after 318 minutes. When the temperature is below $0{ }^{\circ} \mathrm{C}$, the setting time of the normal consistency cement paste significantly shortens in comparison to the setting time at $0{ }^{\circ} \mathrm{C}$.

The initial setting times at $+20{ }^{\circ} \mathrm{C}$ were shortened to 120 minutes by using $1 \% \mathrm{Ca}\left(\mathrm{NO}_{3}\right)_{2}$, were shortened to 105 minutes with $2 \% \mathrm{Ca}\left(\mathrm{NO}_{3}\right)_{2}$ and were shortened nearly three times (up to 45 minutes) with $3 \% \mathrm{Ca}\left(\mathrm{NO}_{3}\right)_{2}$. The comparison of the data shows that the use of $1 \%$ 


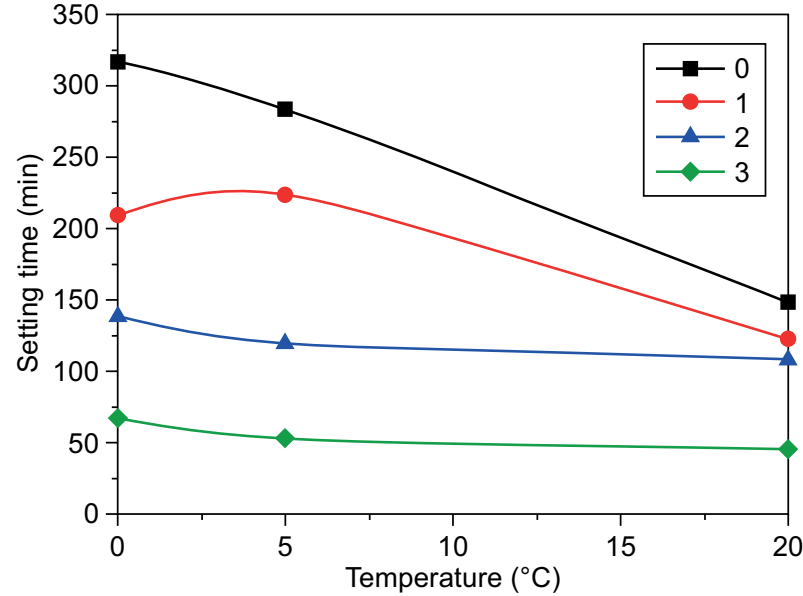

Figure 2. The Portland cement paste with and without $\mathrm{Ca}\left(\mathrm{NO}_{3}\right)_{2}$, the initial setting time at the different initial curing temperatures.

$\mathrm{Ca}\left(\mathrm{NO}_{3}\right)_{2}$ reduces the initial setting time $19 \%, 30 \%$ for the $2 \%$ dosage and $67 \%$ for the $3 \%$ dosage. It can be seen that the dependencies obtained in the hydration temperature study have been confirmed.

The investigation at $5{ }^{\circ} \mathrm{C}$ shows that even the $1 \%$ $\mathrm{Ca}\left(\mathrm{NO}_{3}\right)_{2}$ dosage is effective at shortening the initial setting time by 61 minutes. The comparison of the data with the data without $\mathrm{Ca}\left(\mathrm{NO}_{3}\right)_{2}$ shows that the use of $1 \%$ $\mathrm{Ca}\left(\mathrm{NO}_{3}\right)_{2}$ reduces the initial setting time by $21 \%, 58 \%$ for the $2 \%$ dosage and $81 \%$ for the $3 \%$ dosage.

The investigation at $0{ }^{\circ} \mathrm{C}$ shows that at this temperature, the effect of $\mathrm{Ca}\left(\mathrm{NO}_{3}\right)_{2}$ is even more pronounced. After using the $1 \% \mathrm{Ca}\left(\mathrm{NO}_{3}\right)_{2}$ dose in the cement paste, the initial setting time is reduced by 110 minutes. The comparison of the data with the data without $\mathrm{Ca}\left(\mathrm{NO}_{3}\right)_{2}$ shows that the use of $1 \% \mathrm{Ca}\left(\mathrm{NO}_{3}\right)_{2}$ reduces the initial setting time by $34 \%, 56 \%$ for the $2 \%$ dosage, and $79 \%$ for the $3 \%$ dosage. The results of these studies are confirmed by other research on the investigations of the setting times [28].

The final setting times of the tested cement pastes at the abovementioned temperatures (Figure 3) largely corresponds to the trends described in the initial setting time research results.

When testing at $-5{ }^{\circ} \mathrm{C}$ was performed, the significant shortening of the setting times was observed when compared to the data at $0{ }^{\circ} \mathrm{C}$ (Table 3 ). When the ambient temperature is below $0{ }^{\circ} \mathrm{C}$, the water freezing processes

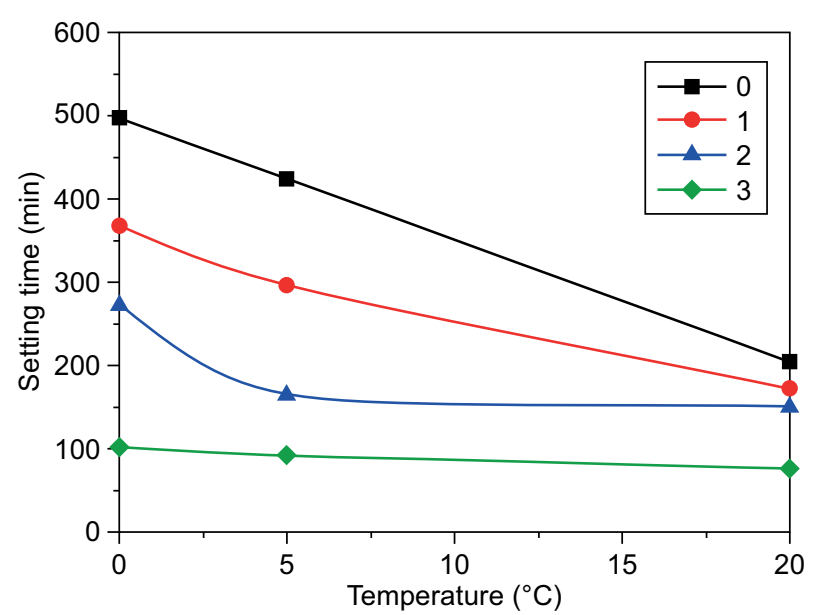

Figure 3. The Portland cement paste with and without $\mathrm{Ca}\left(\mathrm{NO}_{3}\right)_{2}$, the final setting time at the different initial curing temperatures.

begin to predominate, the hydration processes in the cement slow down or stop and it is difficult to separate the binding processes precisely according to the commonly used test methodology. Compared to the investigation at $0{ }^{\circ} \mathrm{C}, 1 \% \mathrm{Ca}\left(\mathrm{NO}_{3}\right)_{2}$ has no effect on the initial setting time of the cement paste. This dose of $\mathrm{Ca}\left(\mathrm{NO}_{3}\right)_{2}$ did not reduce the freezing point of the water [6]. Only $2 \%$ and $3 \% \mathrm{Ca}\left(\mathrm{NO}_{3}\right)_{2}$ in the paste have an influence on the setting times.

The investigation at $-10{ }^{\circ} \mathrm{C}$ shows that $1 \%$ $\mathrm{Ca}\left(\mathrm{NO}_{3}\right)_{2}$ reduces the initial setting time of the cement paste to 100 minutes. The higher doses of $2 \%$ and $3 \%$ $\mathrm{Ca}\left(\mathrm{NO}_{3}\right)_{2}$ in the paste practically do not change the initial setting times. The dose of $1 \% \mathrm{Ca}\left(\mathrm{NO}_{3}\right)_{2}$ lowered the freezing point of the water, but the higher $\mathrm{Ca}\left(\mathrm{NO}_{3}\right)_{2}$ content did not affect it. The effectiveness of $\mathrm{Ca}\left(\mathrm{NO}_{3}\right)_{2}$ in reducing the freezing point of water is related to its amount in the solution and the eutectic point. The eutectic point is the lowest temperature at which the addition of $\mathrm{Ca}\left(\mathrm{NO}_{3}\right)_{2}$ does not lower the freezing point of water [1, 7]. The apparent temperature of $-10{ }^{\circ} \mathrm{C}$, in this case, is the eutectic point for this cement mixture with the $\mathrm{Ca}\left(\mathrm{NO}_{3}\right)_{2}$ admixture. When decreasing the temperature until $0{ }^{\circ} \mathrm{C}$, the final setting times in all the tested cement pastes increased and when the temperature was below $0{ }^{\circ} \mathrm{C}$, the significant shortening of the final setting time was observed.

It can be indicated that the efficiency of $\mathrm{Ca}\left(\mathrm{NO}_{3}\right)_{2}$ as

Table 3. The setting time at the temperatures of $-5{ }^{\circ} \mathrm{C}$ and $-10{ }^{\circ} \mathrm{C}$

\begin{tabular}{ccccc}
\hline $\begin{array}{c}\text { Dosage of } \\
\mathrm{Ca}\left(\mathrm{NO}_{3}\right)_{2}\end{array}$ & \multicolumn{2}{c}{ Initial setting time, minutes at temperature } & & \multicolumn{2}{c}{ Final setting time, minutes at temperature } \\
\cline { 2 - 5 } \cline { 5 - 5 } & $-5{ }^{\circ} \mathrm{C}$ & $-10^{\circ} \mathrm{C}$ & $-5{ }^{\circ} \mathrm{C}$ & 183 \\
\hline 0 & 120 & 158 & 180 & 185 \\
2 & 120 & 108 & 177 & 166 \\
3 & 110 & 120 & 186 & 161 \\
\hline
\end{tabular}


an accelerator increases with the decreasing temperature in the temperature range of $+20{ }^{\circ} \mathrm{C}$ to $0{ }^{\circ} \mathrm{C}$. It should be noted that $\mathrm{Ca}\left(\mathrm{NO}_{3}\right)_{2}$ is the most effective at $5{ }^{\circ} \mathrm{C}$ and $0{ }^{\circ} \mathrm{C}$.

\section{Properties of the concrete mixtures and hardened concrete}

The results of the concrete mixture's technological properties measurement are summarised in Figure 4. The fluidity of the concrete mixture has been determined twice, right after mixing and after 1 hour. The dose of $\mathrm{Ca}\left(\mathrm{NO}_{3}\right)_{2}$ increases the consistency a little after mixing the concrete mixture with CEM I 42.5 R. Other researchers also indicated similar effects [1]. After one hour, it could be observed that there is a tendency that an increase in the $\mathrm{Ca}\left(\mathrm{NO}_{3}\right)_{2}$ dosage does not have a significant effect on the consistency of the concrete mixture (Figure 4). The content of $\mathrm{Ca}\left(\mathrm{NO}_{3}\right)_{2}$ had no impact on the density of the concrete mixture with the CEM I $42.5 \mathrm{R}$ cement.

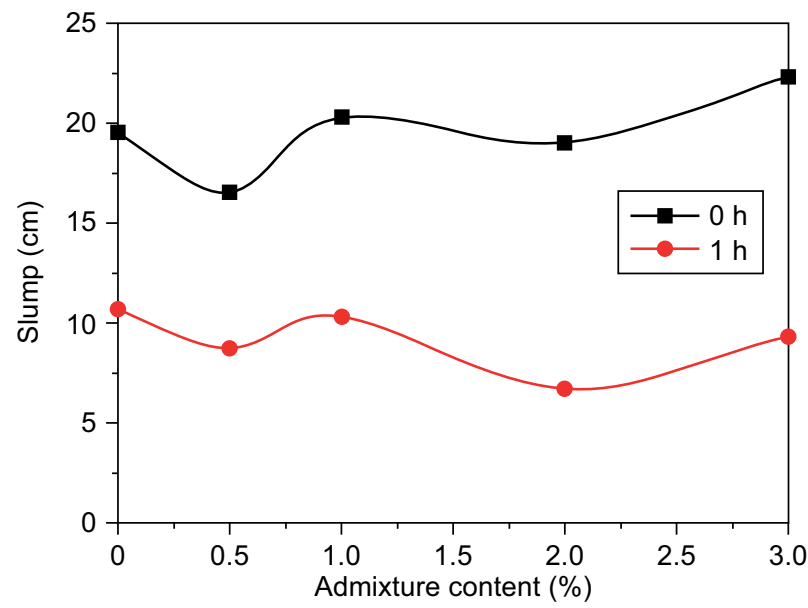

Figure 4. The consistency of the concrete mixture with $\mathrm{Ca}\left(\mathrm{NO}_{3}\right)_{2}$.

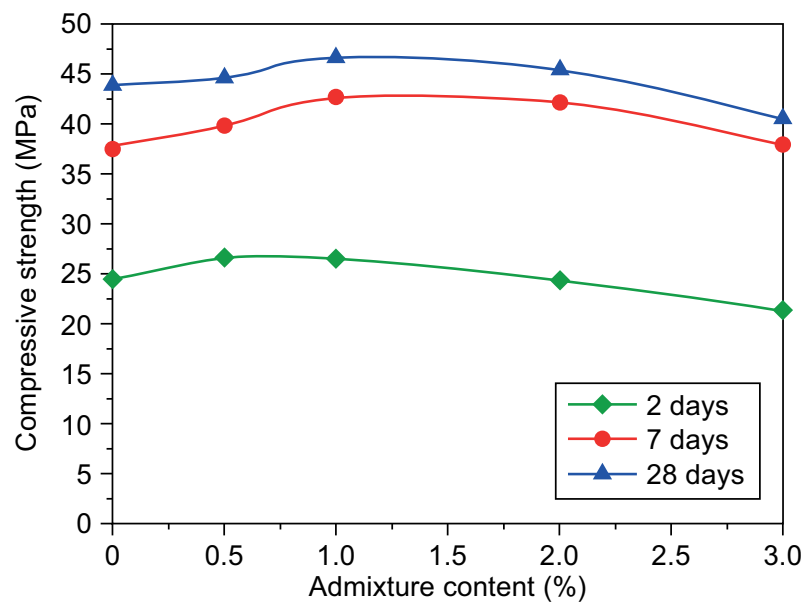

Figure 6. The compressive strength of the concrete samples at the $20{ }^{\circ} \mathrm{C}$ initial curing temperature.
The density of the concrete mixture ranged from 2376 to $2386 \mathrm{~kg} \cdot \mathrm{m}^{-3}$ with a difference of only $10 \mathrm{~kg} \cdot \mathrm{m}^{-3}$.

The air content in the concrete mixtures with CEM I $42.5 \mathrm{R}$ ranged from $4.6 \%$ to $5.2 \%$ irrespective of the $\mathrm{Ca}\left(\mathrm{NO}_{3}\right)_{2}$ content (Figure 5). The admixture $\mathrm{Ca}\left(\mathrm{NO}_{3}\right)_{2}$ had no influence on the air content in the concrete mixture.

The results of the concrete compressive strength were determined after 2 days of the initial curing and after the immediate removal from the freezing chamber. The later compressive strength was tested after the following 5 and 26 days of immersion in $20{ }^{\circ} \mathrm{C}$ water. The reference samples were cured at $20^{\circ} \mathrm{C}$ in the water continuously.

When hardening at $20{ }^{\circ} \mathrm{C}$, the best results are obtained with $1 \% \mathrm{Ca}\left(\mathrm{NO}_{3}\right)_{2}$. Compared to the samples without $\mathrm{Ca}\left(\mathrm{NO}_{3}\right)_{2}$, the concrete compressive strength increases by $8.6 \%$ after 2 days by $12.9 \%$ after 7 days and by $6.2 \%$ after 28 days. It can be seen that $\mathrm{Ca}\left(\mathrm{NO}_{3}\right)_{2}$ has some influence on the concrete early strength. The results indicate that $\mathrm{Ca}\left(\mathrm{NO}_{3}\right)_{2}$ alone acts as a setting

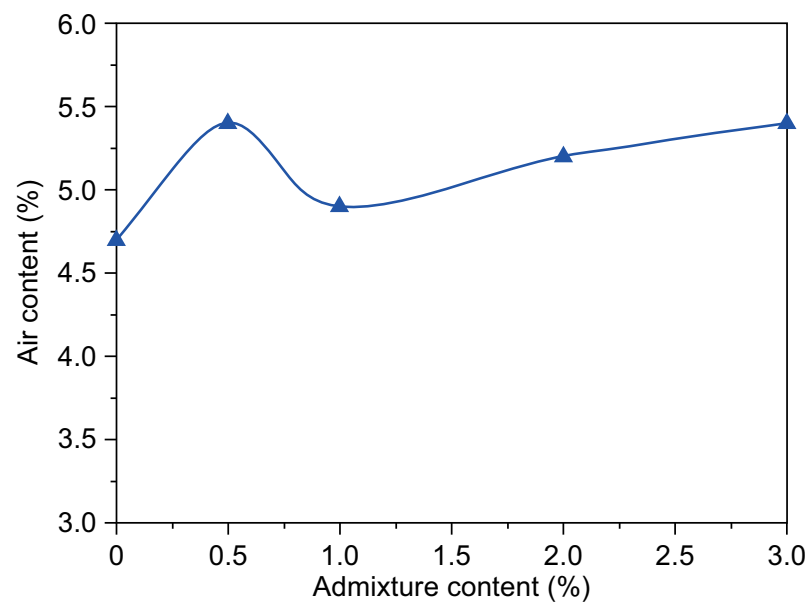

Figure 5. The air content in the concrete mixture with $\mathrm{Ca}\left(\mathrm{NO}_{3}\right)_{2}$.

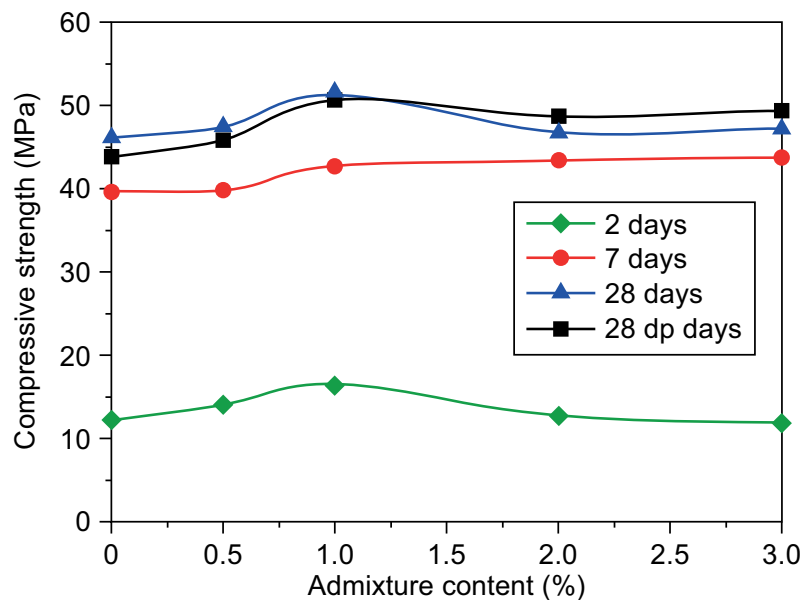

Figure 7. The compressive strength of the concrete samples at the $+5{ }^{\circ} \mathrm{C}$ initial curing temperature $(28 \mathrm{dp}$ - the reference samples prepared and cured at $20^{\circ} \mathrm{C}$ ). 
accelerator, but has a relatively little beneficial effect on the long-term period development of the mechanical resistances [19]. This can be explained by the early onset of the hydration processes, as evidenced by the exothermic studies of the cement paste hydration.

At $5{ }^{\circ} \mathrm{C}$ initial curing, the best results are obtained with $1 \% \mathrm{Ca}\left(\mathrm{NO}_{3}\right)_{2}$ (Figure 7). The compressive strength increases by $34.1 \%$ after 2 days compared to the concrete without $\mathrm{Ca}\left(\mathrm{NO}_{3}\right)_{2}$. Meanwhile, after 28 days of curing, $1 \% \mathrm{Ca}\left(\mathrm{NO}_{3}\right)_{2}$ showed an $11.4 \%$ increase in the compressive strength only.

As shown (Figure 8), the compressive strength of the specimens after 2 days of the initial curing at $0{ }^{\circ} \mathrm{C}$ is above $3.5 \mathrm{MPa}$. At $0{ }^{\circ} \mathrm{C}$, the best results are obtained with $0.5 \% \mathrm{Ca}\left(\mathrm{NO}_{3}\right)_{2}$. After 2 days, the increase in the compressive strength reaches $45.6 \%$. Meanwhile, after 28 days, $0.5 \% \mathrm{Ca}\left(\mathrm{NO}_{3}\right)_{2}$ increases the compressive strength to only $8.7 \%$. The results of the concrete compressive strength for the 2-day freezing are better

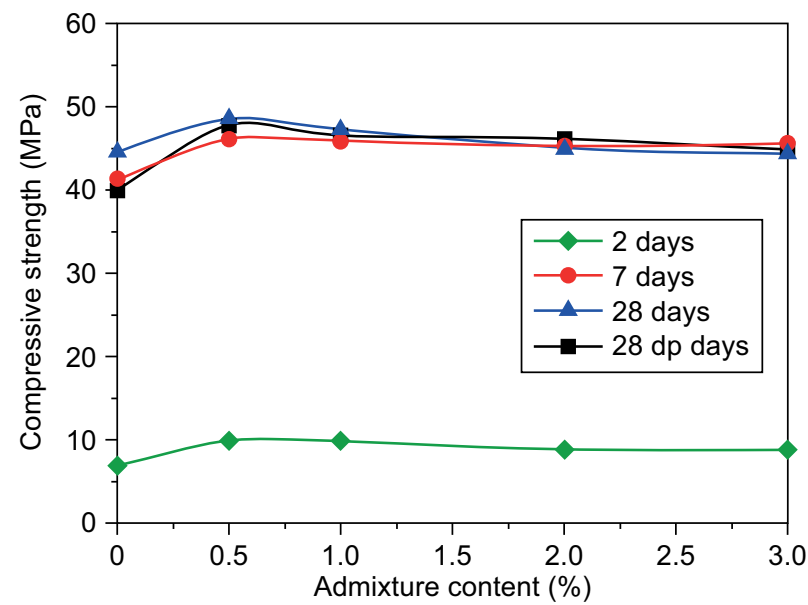

Figure 8 . The compressive strength of the concrete samples at the $0{ }^{\circ} \mathrm{C}$ initial curing temperature $(28 \mathrm{dp}$ - the reference samples prepared and cured at $20^{\circ} \mathrm{C}$ ).

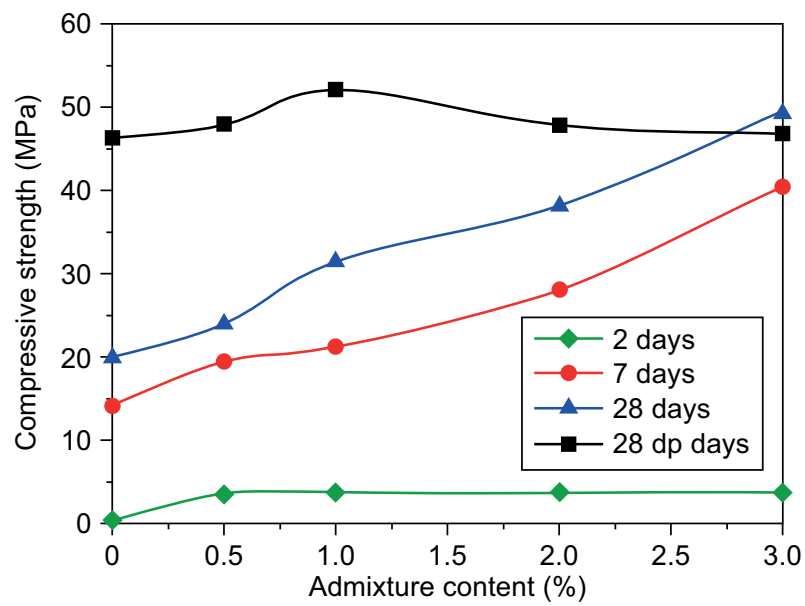

Figure 9. The compressive strength of the concrete samples at the $-5{ }^{\circ} \mathrm{C}$ initial curing temperature $(28 \mathrm{dp}$ - the reference samples prepared and cured at $20^{\circ} \mathrm{C}$ ). than the results of non-freezing samples. Researchers have provided other results with different cooling times and further immersion in water for up to 28 days [1]. It was concluded that when the $\mathrm{Ca}\left(\mathrm{NO}_{3}\right)_{2}$ admixture was used, the additional water curing was necessary for the development of the compressive strength and to gain a high level of compressive strength results, because the water curing (weather conditions often in cold regions are changing from being cold to rainy) may be enough to vitalise the frozen cement paste to gain its original expected compressive strength. The compressive strength value of the frozen concrete specimens with $0.5 \%$ $\mathrm{Ca}\left(\mathrm{NO}_{3}\right)_{2}$ after 28 days is higher compared to the nonfrozen specimens.

A quite clear effect of $\mathrm{Ca}\left(\mathrm{NO}_{3}\right)_{2}$ on the compressive strength of the concrete is observed at $-5{ }^{\circ} \mathrm{C}$. The value of the compressive strength for the concrete with the $3 \%$ $\mathrm{Ca}\left(\mathrm{NO}_{3}\right)_{2}$ dose cured 2 days at $-5{ }^{\circ} \mathrm{C}$ and 26 days at $20^{\circ} \mathrm{C}$ (a total of 28 days) is higher than the value of the reference sample cured for 28 days at $20^{\circ} \mathrm{C}$.

The compressive strength value after two days exceeds 3.5 MPa and reaches 3.7 MPa when using $0.5 \%$ $\mathrm{Ca}\left(\mathrm{NO}_{3}\right)_{2}$. This question is discussed in the introduction [3]. In this case, no additional measures are needed to protect the concrete to achieve the required strength, it is only necessary to provide a sufficient moist environment for the further curing. For 7 days, the best results were obtained with $3 \% \mathrm{Ca}\left(\mathrm{NO}_{3}\right)_{2}$ which was 2.8 times the compressive strength compared to the samples without $\mathrm{Ca}\left(\mathrm{NO}_{3}\right)_{2}$ for 7 days. After 28 days, it also appears that the best dosage is to use $3 \% \mathrm{Ca}\left(\mathrm{NO}_{3}\right)_{2}$. In this case, the strength of the sample is 2.5 times higher than the samples without the $\mathrm{Ca}\left(\mathrm{NO}_{3}\right)_{2}$ admixture.

The samples with $0.5-3 \% \mathrm{Ca}\left(\mathrm{NO}_{3}\right)_{2}$ were cured for 2 days at $-10{ }^{\circ} \mathrm{C}$, but they did not reach the required strength value of 3.5 MPa. This indicates that the application of $\mathrm{Ca}\left(\mathrm{NO}_{3}\right)_{2}$ alone at this temperature is not sufficient and additional measures are required. How-

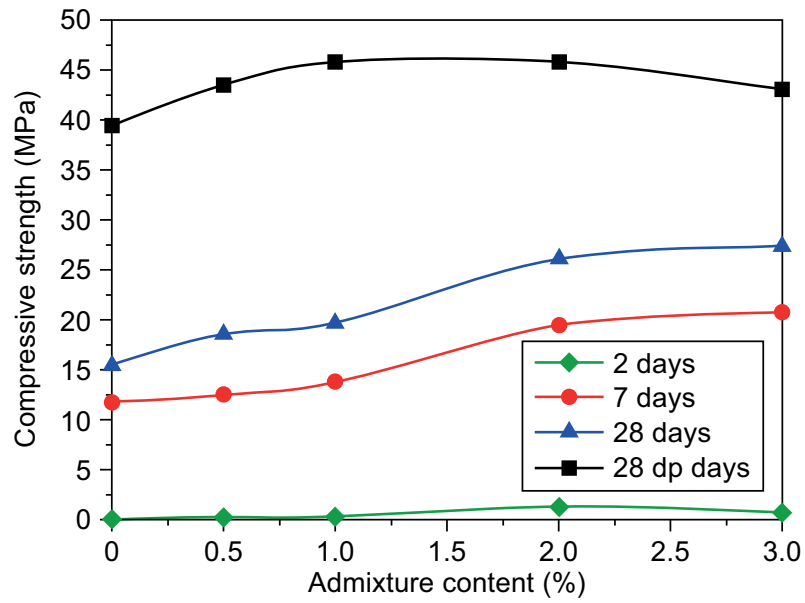

Figure 10. The compressive strength of the concrete samples at the $-10{ }^{\circ} \mathrm{C}$ initial curing temperature $(28 \mathrm{dp}$ - the reference samples prepared and cured at $20^{\circ} \mathrm{C}$ ). 
ever, the further retention of these specimens in water ensures the cement hydration, which results in a significant increase in the concrete compressive strength in the curing water after 7 and 28 days. After 28 days, the best results are obtained with $3 \% \mathrm{Ca}\left(\mathrm{NO}_{3}\right)_{2}$. In this case, the compressive strength is 1.8 times higher than the samples without $\mathrm{Ca}\left(\mathrm{NO}_{3}\right)_{2}$.

To evaluate the dosages of $\mathrm{Ca}\left(\mathrm{NO}_{3}\right)_{2}$ at the different temperatures in more detail, the obtained data of the compressive strength after 2 and 28 days are summarised in Figures 11 and 12.

It can be seen that after 2 days of curing at the different temperatures (Figure 11), the optimal dosage of $1 \%$ $\mathrm{Ca}\left(\mathrm{NO}_{3}\right)_{2}$ ensures higher compressive strength values of the specimens at the different initial curing temperatures. At lower initial curing temperatures equal to $-10^{\circ} \mathrm{C}$, all the tested $\mathrm{Ca}\left(\mathrm{NO}_{3}\right)_{2}$ contents do not provide the sufficient compressive strength of the samples. After 28 days of curing the specimens (Figure 12), it is clear that when

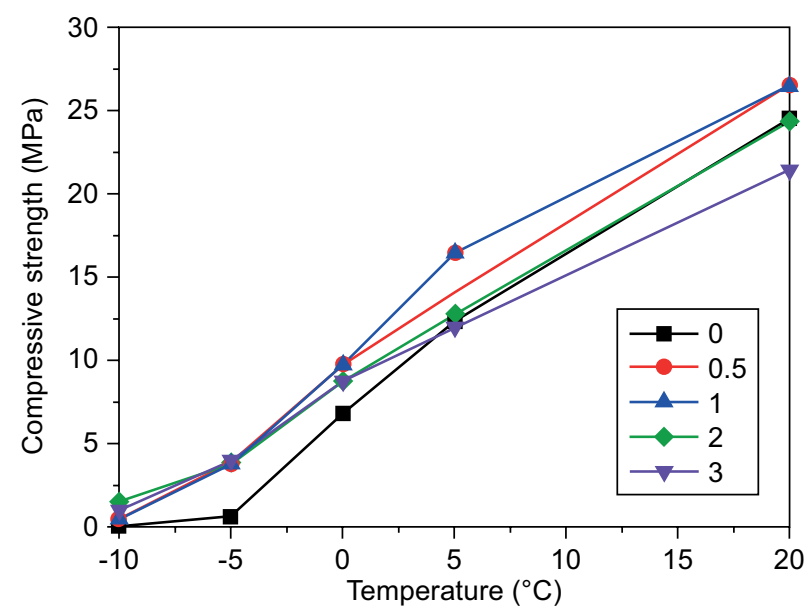

Figure 11. The compressive strength of the concrete samples after 2 days at the different initial curing temperatures.

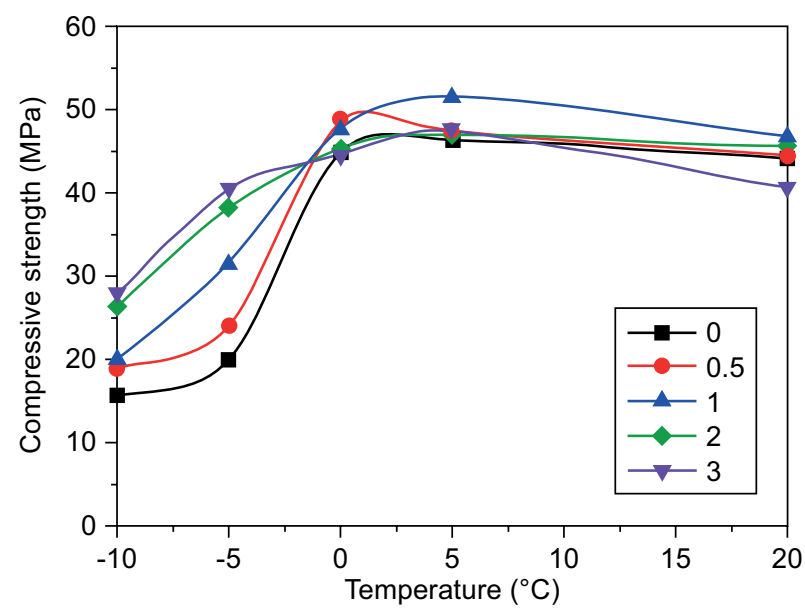

Figure 12. The compressive strength of the concrete samples after 28 days at the different initial curing temperatures. using $\mathrm{Ca}\left(\mathrm{NO}_{3}\right)_{2}$ in the initial curing temperature above $0{ }^{\circ} \mathrm{C}$, the most effective dosage is also $1 \% \mathrm{Ca}\left(\mathrm{NO}_{3}\right)_{2}$. However, at initial curing of $-5{ }^{\circ} \mathrm{C}$ and $-10{ }^{\circ} \mathrm{C}$, the efficiency of $\mathrm{Ca}\left(\mathrm{NO}_{3}\right)_{2}$ directly depends on its content the higher the dosage of $\mathrm{Ca}\left(\mathrm{NO}_{3}\right)_{2}$ is up to $2 \%$, the higher the strength values of the concrete van be achieved.

\section{CONCLUSIONS}

- The $\mathrm{Ca}\left(\mathrm{NO}_{3}\right)_{2}$ admixture in the cement paste shortens the induction period of the cement hydration. In the cement paste without $\mathrm{Ca}\left(\mathrm{NO}_{3}\right)_{2}$, the induction period is the longest - about $3 \mathrm{~h} ; 1 \% \mathrm{Ca}\left(\mathrm{NO}_{3}\right)_{2}$ shortens the induction period and is about 2 hours, $2 \% \mathrm{Ca}\left(\mathrm{NO}_{3}\right)_{2}$ - about 1 hour, and in the cement paste with $3 \%$ $\mathrm{Ca}\left(\mathrm{NO}_{3}\right)_{2}$, the induction period is practically absent

- The higher the $\mathrm{Ca}\left(\mathrm{NO}_{3}\right)_{2}$ dose is, the shorter the time needed to reach the maximum hydration temperature in the cement paste is: $1 \% \mathrm{Ca}\left(\mathrm{NO}_{3}\right)_{2}$ reduces the time by $15 \%, 2 \%$ - by $25 \%$, and $3 \%$ - by $30 \%$. In comparison to the control samples, in which the hydration temperature reaches $91.87^{\circ} \mathrm{C}, 1 \% \mathrm{Ca}\left(\mathrm{NO}_{3}\right)_{2}$ reduces the hydration temperature to $84.8^{\circ} \mathrm{C}, 2 \%$ to $77^{\circ} \mathrm{C}$ and $3 \%$ to $67.91{ }^{\circ} \mathrm{C}$.

- The $\mathrm{Ca}\left(\mathrm{NO}_{3}\right)_{2}$ admixture shortens the setting time of the cement paste. At $0{ }^{\circ} \mathrm{C}$ and $5{ }^{\circ} \mathrm{C}$, this effect is most pronounced. At these temperatures, the use of $1 \%$ $\mathrm{Ca}\left(\mathrm{NO}_{3}\right)_{2}$ reduces the initial setting time to $21.4 \%$ and $34.0 \%, 2 \%$ reduces it to $57.9 \%$ and $56.6 \%$ and $3 \%$ reduces it to $81.4 \%$ and $78.9 \%$. At lower temperatures $\left(-5{ }^{\circ} \mathrm{C},-10{ }^{\circ} \mathrm{C}\right)$, only $3 \% \mathrm{Ca}\left(\mathrm{NO}_{3}\right)_{2}$ can shorten the initial setting time to about $40 \%$.

- The early strength of the specimens cured for 2 days at the different temperatures $\left(+20{ }^{\circ} \mathrm{C}\right.$ and $+5{ }^{\circ} \mathrm{C}$ and $0{ }^{\circ} \mathrm{C}$ ), was improved when the minimal doses of $\mathrm{Ca}\left(\mathrm{NO}_{3}\right)_{2}(0.5$ and $1 \%)$ was used in the composition. For the 2-day specimens cured at the lower indicated temperatures $\left(-5{ }^{\circ} \mathrm{C},-10{ }^{\circ} \mathrm{C}\right)$, higher $(2-3 \%)$ $\mathrm{Ca}\left(\mathrm{NO}_{3}\right)_{2}$ doses improve the standard strength values. The most effective application of $\mathrm{Ca}\left(\mathrm{NO}_{3}\right)_{2}$ is achieved at $-5{ }^{\circ} \mathrm{C}$. After two days of initial curing in the low temperature, the strength of the concrete with $\mathrm{Ca}\left(\mathrm{NO}_{3}\right)_{2}$ exceeds $3.5 \mathrm{MPa}$.

- By using the methodology when the samples are cured for 2 days at the cold conditions and later cured at $20^{\circ} \mathrm{C}$ for 26 days, the compressive strength values are bigger than the compressive strength values of the samples which are cured in water at $20^{\circ} \mathrm{C}$ continuously.

\section{REFERENCES}

1. Karagöl F., Demirboğa R, Kaygusuz M.A, Yadollahi M.M, Polat, R. (2013): The influence of calcium nitrate as antifreeze admixture on the compressive strength of concrete exposed to low temperatures. Cold Region Science and Techno$\log y, 89,30-35$. doi: 10.1016/j.coldregions.2013.02.001 
2. Polat R., Demirboğa R., Karakoç M.B., Tükmen I. (2010): The influence of lightweight aggregate on the physicomechanical properties of concrete exposed to freeze-thaw cycles. Cold Regions Science and Technology, 60(1), 51-56. doi: 10.1016/j.coldregions.2009.08.010

3. ACI 306R - 10 (2010). Guide to Cold Weather Concreting First Printing October pp. 1-26.

4. Ramachandran V.S. (1995). Concrete Admixtures Handbook, Second edition. pp. 740-756.

5. Huang H., Shen X-D. (2011): Statistical study of cement additives with and without chloride on performance modification of Portland cement. Progress in Natural Science: Materials International, 21 (2), 246-253.doi: 10.1016/ S1002-0071(12)60038-0

6. Korhonen C.J, Cortez, E.R. (1991): Antifreeze admixtures for cold weather concreting. Concrete International, 13(3), 38-41.

7. Korhonen C.J, Orchino S. A. (2001). Off-the-shelf antifreeze admixtures. Technical Report TR-01-02. US Army Corps of Engineers, Engineer Research and Development Center, $1-23$

8. Nmai C.K. (1998): Cold weather concreting admixtures. Cement and Concrete Composites, 20, 121-128. doi: 10. 1016/S0958-9465(97)00063-2

9. Korhonen C. (2002). Off-the-shelf antifreeze admixtures. Technical Report TR02-07. US Army Corps of Engineers, Engineer Research and Development Center, 38.

10. Korhonen C. (2002). Effect of high doses of chemical admixtures on the freeze thaw durability of Portland cement concrete. Technical Report TR02-05, pp. 1-38.

11. Hu S., Yang H., Liu S., Chen D., Dollimore D. (1994): Kinetic analysis of the hydration of $3 \mathrm{CaO} \cdot 3 \mathrm{Al}_{2} \mathrm{O}_{3} \cdot \mathrm{CaSO}_{4}$ and the effect of adding $\mathrm{NaNO}_{3}$. Thermochimica Acta, 246 (1), 129-140. doi: 10.1016/0040-6031(94)85099-2

12. Chen D., Dollimore D. (1995): Kinetic analysis of calcium hydroxide formed in the hydration of pure $\mathrm{C}_{3} \mathrm{~S}$ and with addition of $\mathrm{Ca}\left(\mathrm{NO}_{3}\right)_{2}$. Journal of Thermal Analysis, 44, 1001-1011. doi: 10.1007/BF02547528

13. Abdelrazig B.E.I., Bonner D.G, Nowell D.V., Dransfield J.M., Egan P.J. (1999): The solution chemistry and early hydration of ordinary Portland cement pastes with and without admixtures. Thermochimica Acta, 340-341, 417-430. doi: 10.1016/S0040-6031(99)00286-5

14. Hanna R.A., Cheeseman C.R., Hills C.D., Sollars C.J., Büchler P.M., Perry R. (1995): Calcium hydroxide formation in cement- solidified industrial wastes Environmental Technology, 15, 1001-1008. doi: 10.1080/0959333 1608616338

15. Cheung J., Jeknavorian A., Roberts L., Silva D. (2011): Impact of admixtures on the hydration kinetics of Portland cement. Cement and Concrete Research, 41(21), 1289-1309. doi:10.1016/j.cemconres.2011.03.005
16. Chikh N., Cheikh-Zouaoui Ę.M., Aggoun Ę. S., Duval Ę.R. (2008): Effects of calcium nitrate and triisopropanolamine on the setting and strength evolution of Portland cement pastes Materials and Structures,41,31-36.doi:10.1617/ s11527-006-9215-8

17. Rear K., Chin D. (1990): Non-chloride accelerating admixtures for early compressive strength. Concrete International, 12 (10), 55-58.

18. Smith P. (1987): Effects of two no-chloride accelerating agents on setting characteristics of Portland cement mortars. American Concrete Institute, ACI SP-102, 25-34.

19. Polat R. (2016): The effect of antifreeze additives on fresh concrete subjected to freezing and thawing cycles. Cold Regions Science and Technology, 127, 10-17. doi:10.1016/j. coldregions.2016.04.008

20. Ramachandran, V.S. (1972): Elucidation of the role of chemical admixtures in hydrating cements by DTA technique. Thermochimica Acta, 4 (3-5) 343-366. doi: 10.1016/ 0040-6031(72)87017-5.

21. Justnes H. (1993). Report STF70 F93138, SINTEF Structures and Concrete, Trondheim, Norway, p. 40.

22. Justnes H., Nygaard E.C. (1995): Technical calcium nitrate as set accelerator for cement at low temperatures. Cement and Concrete Research, 25 (8), 1766-1774. doi: 10.1016/ 0008-8846(95)00172-7

23. Justnes H. (2007): Calcium nitrate as multifunctional concrete admixture. in: Slovenian $14^{\text {th }}$ Slovenian colloquium on Concrete, Ljubljana, Slovenia, pp. 21-28.

24. Popovics S. (1992). Concrete materials, Properties, Specifications and Testing (Chapter 6), $2^{\text {nd }}$ edition. William Andrew Publishing, Noyes, pp. 236-246.

25. Franke W., Weger D., Skarabis J., Gehlen, G. (2016): Study on Calcium Nitrate impact on Carbonation of Concrete. in: Proceeding of $1^{\text {st }}$ International Conference on Grand Challenges in Construction Materials.

26. EN 934-2:2009 (2009). Admixtures for concrete, mortar and grout - Part 2: Concrete admixtures - Definitions, requirements, conformity, marking and labelling.

27. Aggoun S., Cheikh-Zouaoui M., Chikh N., Duval R. (2008): Effect of some admixtures on the setting time and strength evolution of cement pastes at early ages. Construction and Building Material, 22(2) 106-110.doi:10.1016/j. conbuildmat.2006.05.043

28. Ogunbode E.B., Hassan I.O. (2011): Effect of Calcium Nitrate on Selected Properties of Concrete Containing Volcanic Ash. Leonardo Electronic Journal of Practices and Technologies, 19, 29-38.

29. Alcoa Industrial Chemicals (1999). Alcoa calcium aluminate cement test methods brochure, revision 5, available through Alcoa Industrial Chemicals, Frankfurt, 1999 (08/99). 